\title{
СОЦІАЛЬНІ ПОСЛУГИ
}

Doi: https://doi.org/10.15407/dse2018.01.073

УДК 377:005.2

JEL CLASSIFICATION: I21, I29

\author{
B.M. НОВIКОВ \\ д-р екон. наук, проф. \\ Інститут демографії та соціальних \\ досліджень ім. М.В. Птухи НАН України \\ 01032, Україна, м. Київ, бул. Т. Шевченка, 60 \\ E-mail: valery.economy@ukr.net
}

\section{БЮДЖЕТНИЙ РИЗИК: ЗМІСТ ТА РЕГУЛЮВАННЯ У СОЦІАЛЬНІЙ ІНФРАСТРУКТУРІ}

Стаття присвячена питанням економічного розвитку соціальної інфраструктури. Проаналізовано ризики бюджетної системи, з якими стикається економіка соціальних закладів. Розглядаються питання трансферної політики і завдання переходу на удосконалені цінові механізми реалізації послуг. Охарактеризовано розвиток науки ризикології, яка знаходиться на етапі становлення. Відзначено, що ще недостатньо розроблені теоретичні положення і методи оцінки бюджетного ризику. Надано трактовку ризику як бюджетної дефініції. Сформульовано предмет і суб'єкт бюджетного ризику, що забезпечує раціональний підхід до регулювання процесу бюджетування на договірній контрактній основі.

Обгрунтовано, що недоліки фінансової практики місцевого самоврядування пов'язані з не визначенням інституціональних механізмів бюджетування. Трансфертна політика формується без застосування поняття «бюджетної послуги», що призводить до неконтрольованого використання коштів. Бюджетна послуга як фінансова категорія має стати основним елементом планування фінансових ресурсів на місцевому рівні і формування на цій основі держсавного замовлення на надання бюджетних послуг. Державне замовлення повинно орієнтуватись на державні соціальні стандарти та гарантії, соціальні норми і нормативи споживання послуг. Методологія формування державного замовлення передбачає вартісну оцінку бюджетної послуги. Викладено формалізовані методи визначення цін на бюджетні послуги як інструмент формування державного замовлення.

Проаналізовано державний пакет бюджетної послуги в системі охорони здоров'я і визначено необхідність його подальшого структурування. Детально висвітлена структура загальних витрат на охорону здоров'я в Україні, що може бути корисним для формування державного замовлення на бюджетні послуги, $i$ де визначена усе більша роль недержавних витрат на медичне обслуговування населення. Запропоновано заходи з підвищення сталості місцевих бюджетів і забезпечення доступності бюджетних послуг.

Ключові слова: бюджетний ризик, державне завдання, бюджетна послуга, соціальна інфраструктура, трансферти, загальні витрати на охорону здоров'я. 


\section{В.Н. Новиков}

д-р экон. наук, проф.

Институт демографии и социальных

исследований им. М.В. Птухи НАН Украины

01032, Украина, г. Киев, бул. Т. Шевченко, 60

E-mail: valery.economy@ukr.net

\section{БЮДЖЕТНЫЙ РИСК: СОДЕРЖАНИЕ И РЕГУЛИРОВАНИЕ В СОЦИАЛЬНОЙ ИНФРАСТРУКТУРЕ}

Статья посвящена вопросам экономического развития социальной инфраструктуры. Проанализированы риски бюджетной системы, с которыми сталкивается экономика социальных учреждений. Рассмотрены вопросы трансферной политики и задачи перехода на усовершенствованные ценовые механизмы реализации услуг трансфертной политики. Охарактеризовано развитие науки рискологии, находящейся на этапе становления. Отмечено, что еще недостаточно разработаны теоретические положения и методы оценки бюджетного риска. Предоставлена трактовка риска как бюджетной дефиниции. Сформулированы предмет и субъект бюджетного риска, что обеспечивает рациональный подход к регулированию процесса бюджетирования на договорной контрактной основе.

Обосновано, что недостатки финансовой практики местного самоуправления связаны с неопределённостью институциональных механизмов бюджетирования. Трансфертная политика формируется без использования понятия «бюджетной услугш», что приводит к неконтролируемому использованию средств. Бюджетная услуга как финансовая категория должна стать основным элементом планирования финансовых ресурсов на местном уровне и формирования на этой основе государственного заказа на оказание бюджетных услуг. Государственный заказ должен ориентироваться на государственные социальные стандарты и гарантии, социальные нормы и нормативы потребления услуг. Методология формирования государственного заказа предусматривает стоимостную оценку бюджетной услуги. Изложены формализованные методы определения цен на бюджетные услуги как инструмент формирования государственного заказа.

Проанализирован государственный пакет бюджетной услуги в системе здравоохранения и определена необходимость его дальнейщего структурирования. Подробно освещена структура общих расходов на здравоохранение в Украине, что может быть полезным для формирования государственного заказа на бюджетные услуги, где определена возрастающая роль негосударственных расходов на медицинское обслуживание населения. Предложены меры по повышению устойчивости местных бюджетов и обеспечения доступности бюджетных услуг.

Ключевые слова: бюджетный риск, государственное задание, бюджетная услуга, социальная инфраструктура, трансферты, общие расходы на здравоохранение.

\section{V.M. Novikov}

Dr. Sc. (Economics), Prof.

Ptoukha Institute for Demography and Social Studies

of the National Academy of Sciences of Ukraine

01032, Ukraine, Kyiv, blvd Taras Shevchenko, 60

E-mail: valery.economy@ukr.net

\section{THE BUDGET RISK: MEANING AND REGULATION IN SOCIAL INFRASTRUCTURE}

The article is devoted to the issues of economic development of social infrastructure. The risks of the budget system faced by the economy of social institutions are analyzed. The problems of transition to improved price mechanisms for the implementation of services and of transfer policies and are considered. The development of the science of riskology, which is currently in a formative state, is characterized. It is noted that theoretical positions and methods of estimating budgetary risk have not been developed yet. The interpretation of risk as a budget system is given. The object and the subject of budgetary risk are formulated, which provides a rational approach to regulating the budgeting process on a contractual basis.

It is substantiated that the shortcomings in the financial practice of local self-government are connected with the uncertainty of the institutional mechanisms of budgeting. Transfer policy is formed without using the concept of "budgetary services", which leads to uncontrolled use of funds. Budgetary service as a financial category should 
become the main element of planning financial resources at the local level and the formation on this basis of a state order for the provision of budgetary services. The state order should be guided by the state social standards and guarantees, social norms and norms of consumption of services. The methodology of forming a state order provides for a cost estimate of the budgetary service. Formalized methods for determining prices for budgetary services as a tool for forming a state order for services are presented.

The state package of budgetary services in the health care system is analyzed and the need for its further structuring is determined. The structure of the total expenditure on health care in Ukraine is detailed, which can be useful for the formation of a state order for budgetary services and where the increasing role of non-government expenditures on medical services for the population is determined. Measures to increase the sustainability of local budgets and ensure the availability of budget services are proposed.

Keywords: budgetary risk, state task, budget service, social infrastructure, transfers, general health care expenditures.

Постановка і актуальність проблеми. Українська регіональна економіка проходить період глибокої трансформації. У найближчі роки доведеться здійснити докорінне оновлення механізму розвитку соціальної інфраструктури. Донині кошти, які держава передає на місцевий рівень для фінансування закладів соціальної інфраструктури, не набувають форми державного замовлення.

Завдяки Концепції реформування місцевого самоврядування та територіальної організації влади в Україні та Закону України «Про засади державної регіональної політики» одним із важливих нормативних інструментів ефективного фінансування місцевих бюджетів стає бюджетна послуга. Водночас у Бюджетному кодексі України категорія бюджетної послуги відсутня як завдання, що встановлює вимоги до якості, складу, умов, порядку та результативності надання послуг за рахунок державного бюджету. Фінансування бюджетних послуг повинно забезпечуватись на основі державного замовлення, яке формується як завдання на надання послуг за рахунок коштів бюджету.

Необхідно створити модель місцевого розвитку соціальної інфраструктури, у якій поєднати цільові настанови регіональної політики щодо соціальної інфраструктури з бюджетними ресурсами. Подальше використання субвенцій та інших трансфертів передбачає розвиток теоретичних основ бюджетної політики, де головне передовсім треба окреслити важливі дефініції, зокрема бюджетний ризик.

Аналіз досліджень. В економічній науці та у практиці господарської діяльності спостерігається гострий дефіцит досліджень теоретичних питань бюджетних ризиків, вартості державного замовлення та цін на послуги, які надають бюджетні заклади. У науковому плані питання ціни, нормативів і ефективності надання послуг розгляуто в контексті проблеми бюджетування, орієнтованого на результат, наприклад, у працях M.I. Кульчицького (M.I. Kul'chyts'kyj) [1] К.В. Павлюк (K.V. Pavliuk) [2]. 3 іншого боку, вартість бюджетних послуг висвітлена у дослідженнях, присвячених певним галузевим проблемам соціальної інфраструктури. Проте при цьому проаналізовано лише конкретні елементи, які частково утворюють вартість бюджетної послуги. Наприклад, А.B. Ломоносов (A.V. Lomonosov) розглядав заробітну плату як важливий компонент фонду оплати праці та фактор формування державного замовлення на педагогічні послуги [3]. В цілому опрацювання проблеми вартості бюджетних послуг поки не відповідає іiі соціально-економічному значенню і залишається слабо структурованим.

У зв'язку з цим метою статті є визначення поняття бюджетного ризику, дослідження транспарентності бюджетного процесу як однієї з основних передумов ефективного бюджетування, розгляд підходів до формування державного замовлення на 
послуги на вартісній основі і межі, у яких складаються цінові параметри бюджетної послуги. Динаміка і структура витрат на послуги проаналізована на основі системи національних рахунків на прикладі медичних послуг.

Новизна. Запропоновано методологічну базу дослідження бюджетного ризику як одну з системних характеристик бюджетування у соціальній інфраструктурі і ціновий підхід до визначення вартості державного замовлення на послуги з метою подолання невизначеності функціонування соціальних галузей.

Виклад основного матеріалу. Бюджетні проблеми соціальної інфраструктури викликають пильну увагу експертів, особливо в умовах регіональної реформи. Питання дефіциту і бюджетної збалансованості закладів соціальної інфраструктури стають усе більш актуальними в умовах дії ризикованого механізму надання бюджетних трансфертів: дотацій, субвенцій, субсидій тощо. Проте проблематика бюджетних ризиків, які виникають у бюджетній системі, не досліджується в економічній теорії. Бюджетні ризики як наукова категорія не входять у предмет науки ризикології. Сучасна теорія ризиків розглядає ризик у фінансовій сфері як економічне явище, пов'язане з розвитком товаро-грошових відносин, конкуренцією учасників господарського процесу. Фінансовий ризик за сучасним теоретичним трактуванням виникає виключно у ході здійсненя фінансового підприємництва або фінансових операцій і містить у собі імовірність втрат грошових ресурсів [4, с.128]. Недостатність такого підходу до категорії фінансового ризику очевидна з точки зору ризику як складного явища, що має багатоаспектну основу фінансово-бюджетних відносин.

Терміном фінанси означили поняття, пов'язане з системою грошових відносин і утворенням грошових ресурсів, що мобілізуються підприємствами і державою для виконання притаманних їм функцій. Оскільки обсяг грошових коштів як об’єкт розподілу є обмеженим, фінансові відносини є суперечливими. Під впливом цього фактору виникають невизначеності, що є джерелами ризиків, проявлених не тільки на децентралізованому рівні (на рівні суб'єктів господарювання різних форм власності і підпорядкованості), але й на централізованому, тобто на різних рівнях зведеного бюджету від державного і місцевих.

На підставі зазначеного можна сформулювати категорію ризику, тип якого визначений формуванням і виконанням бюджету на основі ряду принципів, в тому числі - ефективності та результативності, цільового використання коштів, справедливості, принципу публічності і прозорості. Бюджетний ризик - це ризик, який виникає при бюджетуванні або в ситуації подолання невизначеності вибору, пов'язаного з імовірністю відхилення бюджету від цільових бюджетних стандартів. Цей висновок корелює з теорією ризику, запропонованою американським економістом, лауреатом Нобелівської премії з економіки (1990) Г. Марковіцем, який вважав, що учасники фінансової та бюджетної діяльності мають на меті зниження невизначеності результату фінансово-бюджетного процесу, чого можна досягти лише за умови створення стабілізації доходної частини фінансового плану [5].

Державна бюджетна політика є частиною фінансової політики і за цілим рядом напрямів їй належить безумовний пріоритет. Державні фінанси активно використовуються у цілях соціального розвитку. Бюджет фінансує 48,7 \% загальних витрат на охорону здоров’я і 83,3 \% загальних витрат на освіту. Їх вплив на соціоекономічні і соціогуманітарні процеси визначений не тільки обсягами бюджетних коштів, залучених у соціальну інфраструктуру, але й адекватними формами і напрямами їх використання. Одним із них, що може забезпечити сталі еволюційні перетворення на територіальному рівні, є залучення недержавних закладів до надання послуг. За- 
конодавство України допускає використання бюджетних коштів суб’єктами господарювання інших форм власності [6].

У ході господарських процесів виникають відхилення від бажаного результату і вимог, визначених державним контрактом (договором), який замовник укладає від імені держави. Вкрай слабка затребуваність причин і наслідків неефективності бюджетних процесів посилює скептичне ставлення до державної бюджетної політики та іiі теоретичних основ. Сталість бюджетів залежить від чіткого уявлення сутності бюджетних ризиків, які мають бути однозначно сприйняті учасниками суспільного діалогу з метою зменшення загроз функціонування державних і недержавних інститутів. У зв’язку з цим необхідно визначити, що є суб’єктом і об’єктом бюджетного ризику. Суб’єктом ризику у цьому випадку є бюджетні організації, а також комерційні і недержавні структури. Конфліктність ризику виявляється у різних аспектах: по-перше, як імовірність під час вибору реципієнта бюджетних коштів; по-друге, як невизначеність у ситуації господарювання. Комплексний підхід дає змогу визначити об'єкт бюджетного ризику. Останнім є державне замовлення як засіб державного регулювання процесу бюджетування шляхом формування на договірній (контрактній) основі якості та обсягів послуг, необхідних для забезпечення пріоритетних потреб держави і населення, розміщення державних контрактів на надання послуг серед бюджетних закладів і суб'єктів господарювання, незалежно від їх форми власності.

Заздалегідь визначений замовником економічний потенціал суб’єкту господарювання та заплановані і оцінені останнім кроки у господарській сфері можуть запобігти хибному витрачанню бюджетних ресурсів і мінімізувати вплив функціональної дії ризиків на споживання послуг, яка характеризується регулятивними властивостями з деструктивними аспектами. Деструктивний аспект регуляторної функції найбільше проявлений у поширенні заміщення бюджетного механізму наданням послуг за ринковими формами і збільшенні обсягів платних послуг у балансі споживання домогосподарств. У загальних витратах на охорону здоров'я питома вага державних бюджетних витрат зменшилась з 52,2 \% у 2012 р. до 44,8 \% у 2016 р., домогосподарств - підвищилась відповідно з 40,2 \% до 52,8 \%. На послуги освіти частка державних бюджетних витрат у загальних витратах складає 85,9 \% у 2016 р., домашних господарств $13,9 \%$. За певними видами освітніх послуг частка витрат домогосподарств дорівнює 40,5-51,9 \% (на придбання інвентаря й обмундирування та на оплату підручників).

Масштаб ризику значною мірою залежить від національної бюджетної політики, яка характеризується ступенем відкритості бюджету. Недостатність вичерпаної та достовірної інформації, що є в наслідком непрозорості бюджету, створює передумови невизначеності і породжує ризики та конфліктність інтересів суб’єктів бюджетного процесу. Найпоширенішими ризиками в ситуації обмеженого доступу до бюджетної інформації є невідповідність доходів витратам, збитковість бюджетів різних рівнів; відхилення отриманого результату від очікуваного; ухвалення помилкових організаційних рішень, що трансформує деструктивну ризикову ситуацію в необхідність залучення небюджетних суб'єктів економічної діяльності у процес надання послуг.

Огляд прозорості бюджету, здійснений і опублікований Міжнародним бюджетним партнерством (International Budget Partnership), виявив великі прогалини щодо бюджетної інформації України. Проекти бюджету, оприлюднені виконавчої владою, містять тільки третину необхідних даних. Деякі взагалі не розроблено, інші розроблено для внутрішнього користування чи публіковано з запізненням. За останні п'ять років динаміка індексу відкритості бюджету в Україні мала негативну тенденцію: він 
зменшився на 16 пунктів. Падіння рівня відкритості бюджету відбулось за рахунок трьох факторів: зниження повноти бюджетної пропозиції, відсутність публікації громадського бюджету, мінімальний обсяг інформації під час аудиторської перевірки виконання бюджету [7].

Залишаються невирішеними важливі питання, зокрема, щодо змістовного зв'язку системи державного стратегування з ефективністю управління державними фінансами, що знижує вплив урядових документів на досягнення фінансової прозорості як умови оцінки соціальних ризиків. Найбільшим недоліком є надлишкова технологічна спеціалізація стратегічних розробок на шкоду їх соціальній спрямованості, недостатнє залучення корпоративних структур та інститутів громадянського суспільства у процеси, що відбуваються на державному і місцевому рівні. У стратегії сталого розвитку «Україна - 2020» лише формально згадана фінансова реформа, не визначено iii напрями. Програмні тези бюджетної резолюції 2018-2020 рр. серед позитивних напрямів містять недостатньо обраховані й доведені положення, що формує додаткові бюджетні ризики для людського розвитку в середньостроковій перспективі. У механізмах досягнення соціальних показників помітна незатребуваність державного замовлення і його вартісної (цінової) компоненти. Поняття національного тарифу для оцінки послуг, застосоване в резолюції, не має всеохопного інституціонального контексту для бюджетної політики.

Державне регулювання соціального розвитку за допомогою цінового механізму визначення вартості послуг бюджетних закладів повинно виходити з того, що бюджет - особлива форма фінансових відносин для нормативного задоволення потреб усього населення і адміністративно-територіальних одиниць. Тому для практики бюджетного фінансування важливим є забезпечення рівномірного розвитку соціальної інфраструктури всієї території країни.

Для практики фінансування місцевого самоврядування такий стан речей це невизначеність системи фінансування завдань на надання бюджетних послуг. Поняття «бюджетної послуги» немає поки чіткого економічного та юридичного трактування. У Бюджетному кодексі України визначення «бюджетної послуги» відсутнє. Водночас бюджетна послуга стає необхідним елементом планування місцевих бюджетів і регулювання діяльності закладів соціальної інфраструктури сучасного на теперішньому етапі реформ охорони здоров'я і освіти, які охоплюють великий обсяг соціально важливих послуг разом із послугами соціального забезпечення, культури, мистецтва, спорту. У ринкових умовах бюджетні послуги мають фінансуватись відповідно до державного замовлення, що є державним планом, і розміщуватись на договірній і конкурсній основі. Юридичний статус замовлення визначено у Законі України «Про державне замовлення для задоволення пріоритетних державних потреб» та у Господарському кодексі України [8, 9].

Попри уведення в цих нормативних документах поняття «державного замовлення» суттєвих змін у системі планування надання послуг на основі договорів (контрактів) не відбулось. Дотепер у договорах не встановлюються вимоги до складу, якості, обсягу, умов, порядку надання бюджетних послуг. Фактично до виконання державного замовлення за рахунок бюджетних коштів не залучені організації недержавної або приватної форм власності. При цьому протягом 2017 р. обсяг невикористаних трансфертних ресурсів, накопичених на казначейських рахунках, збільшився у 3,85 раза.

Одна з причин недосконалості практики застосування інституту державного замовлення - відсутність адекватної системи критеріїв визначення і оцінки завдань. Нормативна-правова база і інструменти бюджетної політики недостатні для укладання 
контрактів на надання послуг. Державне замовлення було визначене у двох Законах України: «Про поставки продукції для державних потреб», «Про закупівлю товарів, робіт і послуг за державні кошти» $[10,11]$. У них всі положення стосовно державного замовлення викладено стисло або формально, а вимоги до укладання завдань представлено переважно адміністративні: найменування, строки, реєстрація тощо [10].

В Україні неодноразово висловлювались пропозиції про доцільність зробити державне замовлення дійсним інструментом бюджетної політики. Це потребує поєднання цільових завдань державного замовлення з розрахунками фінансових нормативів надання бюджетних послуг, оцінкою потреб різних верств населення в обслуговуванні, з критеріями якості і кількості споживання послуг. Вимоги до якості і умов надання послуг за бюджетні кошти мають визначатись відповідно до стандартів якості. Вертикальна система формування процесу надання бюджетних послуг в эï предметній формі представлена в законодавчих документах стосовно медичної реформи.

Зазначені положення певною мірою знайшли відображення у Законі України «Про державні фінансові гарантії надання медичних послуг та лікарських засобів», який прийнято з метою що передбачає реалізацію Концепції реформи фінансування системи охорони здоров’я, затверджену розпорядженням Кабінету Міністрів України від 30.11.2016 № 1013-р.

Перехід до бюджетування, орієнтованого на результат, передбачає формування завдань у вигляді цільових показників державного замовлення, яке містить вимоги до якості та умов надання бюджетних послуг. Важливе значення має орієнтація державного замовлення на соціальні стандарти та гарантії, соціальні норми і нормативи споживання послуг, кошти закладів охорони здоров'я недержавної форми власності та фізичних осіб - підприємців. У сфері медичного обслуговування населення державне замовлення повинно орієнтуватись на державні соціальні стандарти та гарантії, соціальні норми і нормативи споживання послуг. Сукупність згаданих проблем обумовлює розробку нових методичних підходів до процесу формування державного замовлення, спрямованих на розвиток регіональних ринків бюджетних послуг. Нормативи споживання послуг можуть визначатись на основі нормативноправових актів. У сфері дошкільного виховання та загальної освіти вони визначені конституційними нормами ії доступності та стандартами надання бюджетних послуг, які мають бути адекватними програмним завданням освітньої реформи. Аналогічним вбачається підхід до формування державного замовлення, який отримав соціальну форму гарантованого пакету медичного обслуговування. У складі пакету гарантій Міністерством охорони здоров'я України за законом щорічно затверджуватиметься соціальні норми, на основі яких визначатимуться фінансові нормативи. Запропоновані зміни дають змогу залучити до надання медичних послуг за рахунок бюджетних коштів заклади охорони здоров'я недержавної форми власності та фізичних осіб - підприємців. Така законодавча норма мабуть вперше однозначно допускає і стимулює передачу бюджетних коштів підприємницьким структурам, що має позитивно позначитись на якості надання послуг, у т. ч. медичних.

Нормативно-подушне фінансування закладів соціальної інфраструктури зумовлює необхідність суб'єктам бюджетного планування здійснювати розрахунок обсягів муніципальних завдань у сфері їхніх компетенцій. Загалом місцеві бюджетні асигнування на певну бюджетну послугу на середньостроковий період можна розрахувати як добуток кількісного нормативу надання послуг та контингенту споживачів: 


$$
O_{i}=H_{i}^{0} \times N_{i},
$$

де $O_{i}$ - середньостроковий обсяг надання $i$-ої бюджетної послуги; $H^{0}{ }_{i}-$ чисельність споживачів $i$-ої бюджетної послуги; $N_{i}$ - подушний норматив надання бюджетної послуги відповідно населення, грн.

З огляду на реформи у двох великих галузях соціальної інфраструктури - освіти та охорони здоров'я, формування державних завдань відбуватиметься під впливом вартісного фактору. Особливо це стосується медичного обслуговування населення, де послуги надаватимуться за рахунок бюджету і за кошти громадян. У цих умовах питання ціноутворення набуває актуального значення. Вартість бюджетної послуги має бути законодавчо визначена на основі повного врахування витрат на ії надання. У зв'язку з цим важливо взяти до уваги методичну базу оцінки вартості послуг, яка дозволяє використати систему цінової форми завдання у якості ефективного інструменту бюджетної політики. У цьому контексті вартість бюджетної послуги враховує чотири елементи: оплату праці, матеріальні витрати, витрати на утримання будівель та споруд і витрати на комунальні послуги:

$$
P_{i}^{t}=S_{i}^{t}+T_{i}+Q_{i}^{t}+Z_{i}^{t},
$$

де $P_{i}^{t}$ - вартість $i$-ої бюджетної послуги; $S_{i}^{t}$ - витрати на оплату праці; $T_{i}-$ витрати на матеріали та продукти харчування при наданні послуг; $Q_{i}^{t}-$ витрати на утримання будівель та споруд; $Z_{i}-$ комунальні витрати.

Прогнозні показники на наступний рік складання державного бюджету розраховуються методом індексації для кожного виду витрат:

$$
S^{t+1}=S_{i}^{t} \times I^{i+1, p},
$$

де $S^{t+1}{ }_{i}-$ прогнозні витрати на заробітну плату, потрібні для надання бюджетної послуги; $I^{++1, p}-$ індекс-дефлятор витрат на оплату праці.

Аналогічно можна розрахувати прогнозні показники витрат на інші структурні елементи вартості бюджетної послуги:

$$
T^{+1}{ }_{i}=T_{i} \times I^{++1, p},
$$

де $T^{+1}{ }_{i}$ - прогнозні витрати на матеріали та продукти харчування при наданні послуг; $I^{t+l, p}$ - індекс-дефлятор витрат - матеріальні витрати при наданні послуг.

$$
Q_{i}^{t+1}=Q_{i}^{t} \times I^{t+1, p}
$$

де $Q^{t+1}{ }_{i}$ - прогнозні витрати на утримання будівель та споруд; $I^{I^{+1, p}}-$ індекс-дефлятор витрат утримання будівель і споруд.

$$
Z^{++1}=Z_{i} \times I^{++1, p}
$$

де $Z^{++1}$ - прогнозні витрати на оплату комунальних послуг; $I^{i+1, p}-$ індекс-дефлятор на комунальні послуги. 
Під час передання бюджетних ресурсів до недержавних і приватних закладів вартість одиниці послуги, які вони надаватимуть, може встановлюватись на рівні нижчому, ніж у державних закладах. Це пояснюється необхідністю конкурентного відбору закладів для більш ефективного надання послуг за бюджетні кошти, цілеспрямованого використання їх організаційно-матеріального потенціалу, а також кредитних ресурсів. Нижча межа вартості одиниці послуги, що надаватиметься закладами недержавної та приватної форми власності, не може бути меншою за обсяг витрат на надання послуги. Верхня - вище від кінцевої вартості бюджетної послуги для державних закладів соціальної інфраструктури. Граничний тариф визначають так:

$$
P_{i}^{t} \leq K_{i}^{t} \leq N_{i}^{t}
$$

де $K_{i}^{t}$ - вартість одиниці бюджетної послуги, що надаватиметься закладами недержавної і приватної форми власності; $N_{i}^{t}-$ середньоарифметична вартість бюджетної послуги, що надається державними закладами.

Науково-методичне визначення вартості послуг є доцільним з огляду на медичну реформу, у межах якої всі медичні послуги будуть розподілені на повністю безоплатні, частково оплачувані державою (співплатні) та платні. У державний гарантований пакет послуг входитимуть 80 \% найчастіших причин звернень до лікаря, а саме: невідкладна допомога, первинна медична допомога, паліативна допомога. Крім того держава передаватиме свої функції медичного обслуговування населення недержавним закладам. Вартість послуг для лікування серцевосудиних захворювань становитиме 103-130 грн, операції на шлунку - 39-45 тис. грн, лікування травм - 63-71 тис. грн. Перебування в нейрохірургічної лікарні - 10 тис. грн за один день [13]. Ціни на медичні послуги встановлені емпірично і потребують уточнення за науково визначеною методикою. Вони можуть розрізнятись залежно від потужності лікарняного закладу, регіону, технологічної бази та інших ознак. Крім того, розвиватиметься телемедицина, що наблизить рівень медичних послуг в регіонах до рівня столиці і обласних центрів. Застосування телемедичних технологій дає змогу заощадити до $40 \%$ витрат на охорону здоров'я [14].

Для аналітичної оцінки видатків на охорону здоров’я застосовується два варіанти вимірювання у відсотках до ВВП: у першому порівнюються бюджетні видатки, у другому - загальні. У 2016 р. в Україні на медицину спрямовано 3,2 \% ВВП бюджетних видатків. За задовільного рівня зведений бюджет охорони здоров'я має складати мінімум 5 \% ВВП. Що стосується загальних видатків на охорону здоров’я, то міжнародний досвід визначає оптимальний рівень загальних витрат на охорону здоров’я на рівні 8-10 \% ВВП. Відомості щодо країн-членів ЄС це підтверджують. Серед країн колишнього Східного Блоку цим вимогам відповідають Вірменія $10,1 \%$ та Киргизстан - 8,2 \% [15, с. 10]. В Україні фактично обсяг загальних витрат на розвиток охорони здоров'я становить 7,62 \% ВВП [15, с. 10]. Отже, 4,1 \% ВВП вартості медичних послуг або майже 53 \% загальних витрат на охорону здоров'я надаються населенню за «роздрібними» цінами [15, с. 9]. Ідеологія реформи охорони здоров’я передбачає збільшення обсягу платних послуг, що може підвищити їх частку у ВВП до 5 і навіть до $6 \%$.

Представлені підходи до формування державного замовлення враховують необхідність упровадження економічних методів оцінки вартості бюджетних послуг на 
основі чинних соціальних стандартів, що дає змогу контролювати виконання завдань у межах бюджетного планування. На підставі аналізу можна визначати доступність бюджетних послуг і залучення до надання послуг закладів різних організаційноправових форм власності.

Аналітичні розрахунки показують, що вартість бюджетної послуги у сфері медичного обслуговування населення знаходиться відповідно до вищенаведеної формули в інтервалі 1 та 2,5: $1 \leq K_{i}^{t} \leq 2,5$, де нижча межа складає 205 грн, верхня 513 грн за одноразове надання і-ої послуги. Розрахунки виконано на основі показників вартості проміжного споживання, оплати праці та споживання основного капіталу в системі охорони здоров'я за 2015 р. [16, с. 44].

Ціноутворення в охороні здоров'я відіграє ключове значення у визначені державного замовлення на медичні послуги як основний чинник доступності населення до медичного обслуговування. Ефективна організація державного замовлення існуватиме тільки у разі створення адекватної системи, що уможливить об'єктивний аналіз і оцінку структури організації надання медичних послуг у розрізі фінансових потоків та їх оптимізацію та використання з метою нейтралізації нераціональних витрат і обмеження надлишкових прибутків.

Однією з найбільш визнаних систем оцінки використання фінансових ресурсів у медицині є система національних рахунків охорони здоров'я, яка дає достовірне уявлення з щодо надходження коштів в охорону здоров'я. Її доцільно залучати для встановлення цін на медичні послуги. Основна цінність національних рахунків охорони здоров'я полягає в можливості моніторингу витрат на охорону здоров'я за всіма учасниками системи надання медичних послуг та у поєднанні з нефінансовими даними, такими як, наприклад, рівень поглинання ресурсів надавачами послуг, а також у розробці стратегії ефективного фінансування і управління галуззю.

Основними джерелами фінансування охорони здоров'я є місцеві бюджети і кошти домогосподарств, які разом складають 87,5 \% загальних витрат на медичне обслуговування населення. Частка домогосподарств дорівнює 52,8 \%, що свідчить про формування переважного обсягу медичних послуг за ринковими цінами і відсутність контролю з боку державних структур [15, с. 13].

При цьому обсяг коштів місцевих бюджетів у загальних витратах на охорону здоров’я знижувався протягом 2013-2016 рр. (рисунок). Цю тенденцію можна розцінювати незадовільно, оскільки вона суперечить ідеології реформи децентралізації системи управління, коли акцент ставиться на зростанні значення місцевих органів влади у наданні соціально важливих послуг. Для визначення політики ціноутворення на медичні послуги доцільно не тільки аналізувати структуру витрат за джерелами фінансування, а й розглянути розподіл витрат між функціями або між видами послуг. Укрупнюючи деякі статистичні показники функціональної структури загальних витрат, можна бачити, що 2016 р. найбільша їх частка - 39,3 \% спрямовувалась на придбання ліків та медичне обладнання, 21,6 \% - на стаціонарне лікування, 16,1 \% на амбулаторне лікування, 2,7 \% - на реабілітацію, 5,3 \% - на супутні послуги, 1,1 \% - на профілактичні та громадські послуги охорони здоров'я, 7,5 \% - на управління охороною здоров'я, 3,9 та 2,5 \% - на формування капіталу та на іншу діяльність відповідно [15, с. 13]. Безпосередньо 40,7 \% сфери медичних послуг пов'язані наданням первинної, спеціалізованої та високоспеціалізованої допомоги медичних центрах, в поліклініках і лікарнях. 


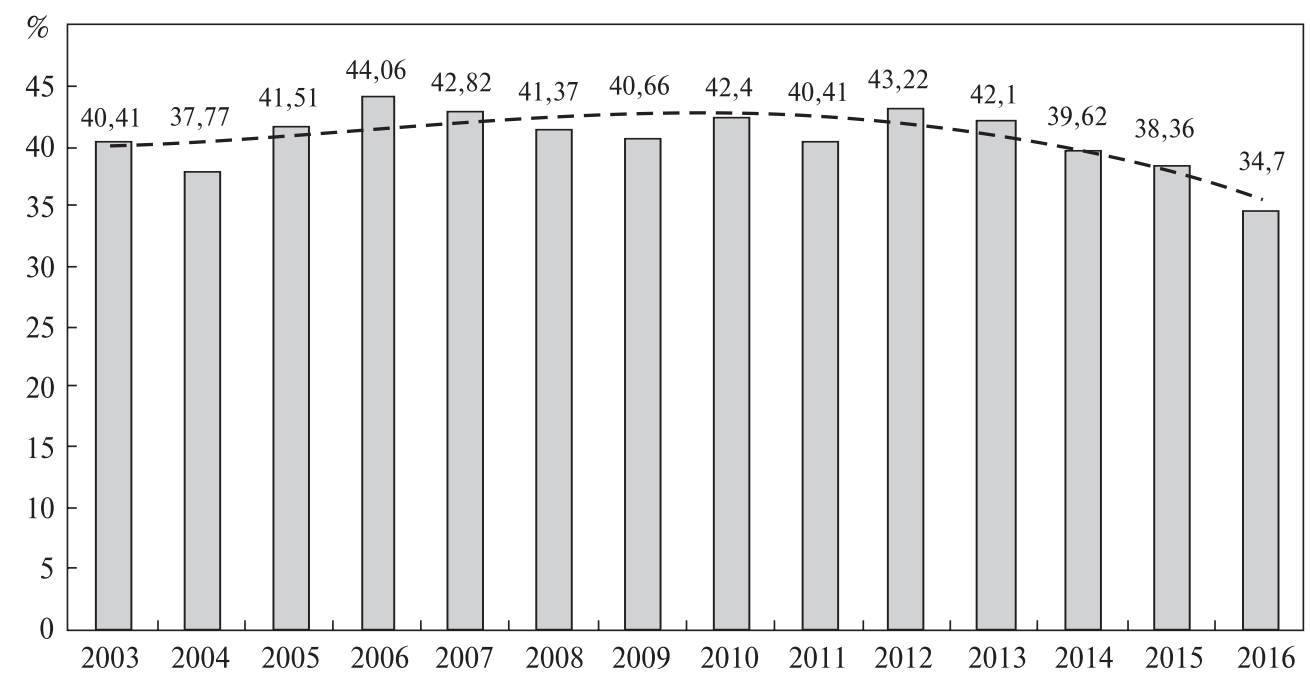

Рис. Частка витрат місцевих бюджетів у загальних витратах на охорону здоров’я,\%1

Джерело: Національні рахунки охорони здоров’я (НРОЗ) України у 2016 році: Стат. Бюллетень / Державна служба статистики України. - К., 2018. - С.157.

У ході медичної реформи структура загальних витрат на охорону здоров’я по функціях має зазнати значних змін, оскільки вводиться гарантований пакет послуг та механізм їх співплати, де 20 \% оплати за медичну допомогу покладається на пацієнтів. Відповідно в структурі загальних витрат на охорону здоров'я по функціях підвищиться частка надавачів амбулаторної допомоги мінімум на 15-20\% на першому етапі. На підставі цього можна оцінити перспективи зміни споживання послуг. Зараз лікарні споживають 91,1 \% суспільних коштів та коштів приватних структур і тільки 8,9 \% коштів домогосподарств. Послуги амбулаторно-поліклінічних закладів поглинають 51,9 \% коштів домогосподарств та приватних фірм і компаній та $42,5 \%$ суспільних коштів [15, с. 14]. Перенесення акценту у медичному обслуговування населення на лікарні підвищить перш за все доходи амбулаторної ланки охорони здоров’я приблизно до 12-17 \%. Отже, співвідношення між державними і приватними джерелами зміниться пропорційно. Одночасно прогресивно зміниться надходження до фінансової системи, насамперед, до бюджетів самоврядних територіальних і місцевих бюджетів, оскільки первинна медична допомога переважно збільшиться на місцевому рівні (таблиця).

Таблиця. Зміна джерел фінансування охорони здоров'я, \%

\begin{tabular}{|l|c|c|}
\hline \multicolumn{1}{|c|}{ Джерела } & До реформи & Після реформи \\
\hline Домогосподарства & 40,7 & $52-69$ \\
\hline Приватні джерела & 50,9 & $48-31$ \\
\hline Надходження до фінансової системи & 0,1 & $10-0$ \\
\hline
\end{tabular}

Джерело: розрахунки на основі зб. Національні рахунки охорони здоров’я (НРО3) України у 2016 році: Стат. Бюлетень / Державна служба статистики України. - К., 2017. - С. 3-25. 
За обсягом надходження зростатимуть й на районному і регіональному рівнях, де розташовані стаціонарні заклади і вартість лікування значно перевищує амбулаторне. Доступність медичної допомоги значною мірою залежить від цін на медичні послуги. За реформою цінова політика в сфері охорони здоров’я проголошує рівність цін на однотипні послуги. Це можливо, якщо матеріальні витрати на послуги не відрізняються по регіонах, чого не може бути через різницю у будівельно-монтажній вартості споруд. У цих умовах досягнення цінового паритету забезпечуватиметься механізмом дотацій.

У системі охорони здоров'я виокремлюється три рівня цін: на амбулаторні послуги, на стаціонарне лікування,на діагностичні процедури. Вартість послуг у закладах первинної медико-санітарної допомоги у 2017 р. визначена Міністерством охорони здоров'я України у розмірі 210 грн, що маже ідентично вищенаведеним розрахункам. Ціни на послуги стаціонарних закладів, опубліковані по вибірковим 193 прайсам, складають в середньому 81773 грн, на діагностичні послуги 85179 грн. [17, 18]

Остаточна вартість одиниці бюджетної послуги, наданої у порядку державного замовлення, повинна відповідати не тільки витратам на оплату праці і матеріальним витратам, але й платоспроможності населення. В Україні потенційно середня вартість медичної послуги після реформування перевищуватиме середню номінальну заробітну плату штатного працівника підприємств, установ та організацій, яка у січні 2018 р. становила 7711 грн, у 10,6 раза $[13,17]$.

Для забезпечення доступності населенню медичних послуг необхідний контроль за встановленням завдань з боку регіональних суб'єктів бюджетного планування і контроль за цінами в рамках системи моніторингу ефективності суспільних фінансів. Ціни на медичні послуги повинні спиратись на стандарти якості бюджетних послуг, що має бути закріплено на законодавчому рівні. В умовах значного перевищення вартості послуг охорони здоров'я понад платіжним потенціалом населення необхідно запроваджувати фінансові преференції або удосконалювати страховий механізм на основі поєднання бюджетних і корпоративних джерел.

Висновки. Модернізація галузей соціальної інфраструктури відбувається в умовах бюджетної реформи на принципах децентралізації, що накладає додаткову відповідальність на органи управління бюджетним процесом з застосуванням моделі нормативно-подушного фінансування. За відсутності досвіду широкомасштабного впровадження нормативної моделі фінансування проблема можливості ресурсного забезпечення закладів соціальної інфраструктури і доступності якісного лікування та сучасної освіти стає гостро дискусійною.

Відповідно до Концепції реформи фінансування системи охорони здоров’я, перехід на нову систему закупівлі медичних послуг супроводжується відокремленням живої праці від уречевленої, тобто за рахунок державного бюджету фінансуватиметься медична послуга або праця лікаря, за рахунок місцевих бюджетів - комунальні витрати, реновація і придбання медичного обладнання, капітальний ремонт закладів охорони здоров'я. Монотонне зниження загальних витрат на охорону здоров'я порівняно з витратами місцевих бюджетів стає одним із важливих факторів загострення проблем регіонів. За таких умов створення механізмів витрат на покриття збитків, які виникають у процесі діяльності закладів соціальної інфраструктури, є складовою управління бюджетними ризиками.

Представлені в статті підходи дають змогу забезпечити сталість місцевих бюджетів, а також відповідність бюджетних витрат реальним потребам в бюджетних послугах і підвищити доступність бюджетних послуг за рахунок зменшення локаль- 
них ризиків дефіциту бюджетної системи. Для цього необхідно, по-перше, у проекті Закону України «Про державне фінансування гарантій надання медичних послуг та лікарських засобів» дозволити на місцевому рівні вводити нові податки і передбачити зміну ставок відрахувань у місцеві бюджети від загальнодержавних податків, по-друге, впровадити формалізовані методи визначення тарифів на бюджетні послуги, які враховують кінцеву їх вартість, включаючи заробітну плату і матеріальні витрати, а також рамкові межі коливання тарифів, що забезпечать контроль за виконанням завдань суб’єктів бюджетування.

\section{ЛІТЕРАТУРА}

1. Кульчицький M.I. Програмно-цільове бюджетування на місцевому рівні / М.I. Кульчицький, С.М. Ємець // Ефективна економіка. - 2015. - № 12 [Електронний ресурс]. - Режим доступу : http://www.economy.nayka.com.ua/?op=1\&z=1269 (дата звернення: 12.01.2018).

2. Павлюк К.В. Оцінка виконання бюджетних програм: результативні проказники / К.В. Павлюк // Фінанси України. - 2005. - № 2. - С. 70-77.

3. Ломоносов А.В. Управління оплатою праці у вищій школі. - Миколаїв : Іліон, 2012 . - 720 с.

4. Лук'янова В.В., Головач Т.В. Економічний ризик. - К. : Академвидав, 2007. - 462 с.

5. Портфельная теория Марковица [Електронний ресурс]. - Режим доступу : https://ru.wikipedia. org/wiki (дата звернення: 12.01.2018).

6. Про схвалення Концепції реформування місцевого самоврядування та територіальної організації влади в Україні : розпорядження Кабінету Міністрів України від 01.04. 2014 р. № 333-р. - 8 с. [Електронний ресурс]. - Режим доступу: zakon3.rada.gov.ua /laws/show/333-2014-p (дата звернення: 12.01.2018).

7. Каминкова И. Индекс открытости бюджета 2015: место Украины в мировом рейтинге [Електронний ресурс]. - Режим доступу: http://hvylya.net/analytics/conomics/indeks-otkryitosti-byudzheta2015-mesto-ukrainyi-v-mirovom-reytinge.html (дата звернення: 18.01.2018).

8. Про державне замовлення для задоволення пріоритетних державних потреб : Закон України [Електронний ресурс]. - Режим доступу: zakon3.rada.gov.ua/lows/show/493/95-вр (дата звернення: 18.01.2018).

9. Господарський кодекс України [Електронний ресурс]. - Режим доступу: zakon.rada.gov.ua/ go/436-15 (дата звернення: 12.01.2018).

10. Про поставки продукції для державних потреб : Закон України Електронний ресурс]. - Режим доступу: zakon.rada.gov.ua/laws/show/1329-14 (дата звернення: 12.01.2018).

11. Про закупівлю товарів, робіт і послуг за державні кошти [Електронний ресурс]. - Режим доступу: zakon 3.rada.gov.ua/lows/show/1490-14 (дата звернення: 12.01.2018).

12. Гаврильева T.Н. Формирование государственных заданий на оказание бюджетных услуг. // Регион: экономика и социология. - 2010. - № 3. - С. $102-114$.

13. Новые цены на операции после медицинской реформы [Електронний ресурс]. - Режим доступу: http: //dnl.dn.ua /medical (дата звернення: 12.01.2018).

14. Беззуб I. Телемедицина в Україні: реалії і перспективи [Електронний ресурс]. - Режим доступу : http://nbuvsap.gov/index.?option=com_content\&view=article\&id=2466:telemed (дата звернення: 12.01.2018).

15. Національні рахунки охорони здоров’я (НРО3) України у 2016 році : Стат. бюлетень / Державна служба статистики України. - К., 2017. - 172 с.

16. Національні рахунки України за 2016 рік. Стат. зб. - К., 2018. - - 185 с.

17. Левчук М. Медична реформа: геноцид чи панацея для українців? [Електронний ресурс]. - Режим доступу : Kolo.news/category/zdorove/5984 (дата звернення: 12.01.2018).

\section{REFERENCES}

1. Kul'chyts'kyj, M.I. \& Yemets', S.M. (2015). Prohramno-tsil'ove biudzhetuvannia na mistsevomu rivni [Program budgeting at the local level]. Efektyvna ekonomika - Effective ekonomy, 12. economy.nayka. com.ua. Retrieved from http://www.economy. nayka.com.ua/ ?op=1\&z=1269 [in Ukrainian]. 
2. Pavliuk, K.V. (2005). Otsinka vykonannia biudzhetnykh proharam: rezul'tatyvny prokaznyky [Evaluation of of budget programs: performance indicators]. Finansy Ukrainy - Finance of Ukraine, 2, 70-77 [in Ukrainian].

3. Lomonosov, A.V. (2012). Management of salary in higher education. Ilion [in Ukrainian].

4. Lukyanova, V.V., \& Golovach, T.V. (2012) Economechny rizik [Economic risk]. [in Ukrainian].

5. Portfelnay teorey Markowitza [Portfolio theory of Markowitz]. (n.d.). ru.wikipedia.org. Retrieved from http: //ru.wikipedia.org/wiki [in Russian].

6. Zakon Ukrayiny «Pro chvalenny koncepcii reformuvanny miscevogo samovryduvanny ta terutorialnoii organizacii vladu» [Law of Ukraine «On Approving the Concept of Reforming Local Self-Government and Territorial Organization of Power» [in Ukraine]. (2014). zakono.rada.gov.ua. Retrieved from http://zakon.rada.gov.ua/laws/show/333-2014-p [in Ukrainian].

7. Kaminkova, I. (2016). Index otrutosti bydjetu 2015: mesto Ukrainy v mirovom reytinge [The budget openness index 2015: the place of Ukraine in the world ranking]. hvylya.net. Retrieved from http://hvylya.net/analytics/conomics/indeks-otkryitosti-byudzheta-2015-mesto-ukrainyi-v-mirovomreytinge.html [in Ukrainian].

8. Zakon Ukrayiny «Pro derjavne zamovlenny preorutetnuch potreb» [Law of Ukraine «About the state of the estate for the satisfaction of priority needs»] (2005). zakon0.rada.gov.ua. Retrieved from http: zakon 3.rada. gov.ua /lows/show/493/95-вp [in Ukrainian].

9. Gospodarskii kodeks Ukreiny [Economic Code of Ukraine] (2003). zakon O.rada.gov.ua. Retrieved from http: zakon.rada.gov.ua/go/436-15 [in Ukrainian].

10. Zakon Ukrayiny «Pro postavki produkzii dly derjavnuh potreb» [Law of Ukraine «On Supply of Products for Governmental Needs Electronic resource»] (1995). zakonO.rada.gov.ua. Retrieved from http: zakon.rada.gov.ua/laws/show/1329-14 [in Ukrainian].

11. Zakon Ukrayiny «Pro zakupivly tovariv, robit i poslug za derjabnv kochti». [Law of Ukraine «On procurement of goods, works and services for public funds»] (2000). zakon0.rada.gov.ua. Retrieved from http: zakon.rada. gov.ua zakon /3.rada.gov.ua/lows/show/1490-14 [in Ukrainian].

12. Gavrilieva, T.N. (2010). Formirovanie gocydarstvennuh zadanii na okazanie budjetnuh yslyg. [Formation of government assignments for the provision of budgetary services]. Region: ekonomika $i$ soziologia - Region: economics and sociology, 3, 102-114 [in Russia].

13. Novue zenu na operazii posle medizinskoii reaormu [New prices for surgery after medical reform]. (2017). dnl.dn.ua. Retrieved from http: //dnl.dn.ua /medical [in Ukrainian].

14. Bezzyb, I. (2017). Telemedizina v Yreaine:realii i perspeknivu.[Telemedicine in Ukraine: realities and prospects]. nbuvsap.gov. Retrieved from http: //nbuvsap.gov/index. ?option= com_content\&view=article\&id=2466:telemed [in Ukrainian].

15. Nazionalni raynki ohoronu zdorovay (NROZ) Ykrainu y 2016 rozi [National Health Accounts (NROS) of Ukraine in 2016] (2017). State Statistics Service of Ukraine. ukrstat.gov.ua. Retrieved from http:// www.ukrstat.gov.ua/ [in Ukrainian].

17. Levchuk, M. (2017). Meducha reforma: genozid chi panazeay dlay ykrainzev? [Medical reform: genocide or a panacea for Ukrainians?] Kolo.news. Retrieved from http: Kolo.news/category/zdorove/5984 [in Ukrainian].

Стаття надійшла до редакції журналу 31.01.2018. 